\title{
Diversity of Meliponini and anothers Apiformes (Apidae sensu lato) in a Cerrado fragment and its surrounding, Campo Grande, MS
}

\author{
Antonia Railda Roel ${ }^{1}$, Ricardo Dias Peruca ${ }^{1,2} * \mathbb{B}$, Felipe Varussa de Oliveira Lima ${ }^{3}$, Kwok Chiu Cheung ${ }^{1}$ \\ Armando Araujo Neto ${ }^{I}$, Leticia Vieira Da Silva ${ }^{I} \&$ Suellen Soares ${ }^{I}$ \\ ${ }^{1}$ Universidade Católica Dom Bosco, Campo Grande, MS, Brasil. \\ ${ }^{2}$ Agência de Desenvolvimento Agrário e Extensão Rural - Gerência Desenvolvimento Agrário, Campo Grande, \\ MS, Brasil. \\ ${ }^{3}$ Universidade Federal da Grande Dourados, Dourados, MS, Brasil. \\ *Corresponding author: Ricardo Dias Peruca,e-mail: ricardoperuca@yahoo.com.br
}

ROEL, A. R., PERUCA, R. D., LIMA, F. V. O., CHEUNG, C., ARAUJO NETO, A., SILVA, L. V., SOARES, S. Diversity of Meliponini and anothers Apiformes (Apidae sensu lato) in a Cerrado fragment and its surrounding, Campo Grande, MS. Biota Neotropica. 19(2): e20170333. http://dx.doi.org/10.1590/1676-0611-BN-2017-0333

\begin{abstract}
The aim of this study was to evaluate the diversity of Meliponini and anothers Apiformes (Apidae sensu lato) from a Cerrado fragment and its surrounding. Malaise traps were installed in a pasture near a fragment of Cerrado and its surrounding, from October to December 2010. Samples were collected at seven-day intervals and preserved in Dietrich solution. The apiforms specimens from each sample were separated in morphospecies and sent to identification. The tribe Meliponini was the most abundant in open areas of pasture than in the Cerrado fragment. The Meliponini species present were Trigona gr. fulviventris, Paratrigona lineata, Trigona recursa, Partamona sp, Trigona spinipes, Trigona gr. hyalinata, Trigona gr. fulviventris, Tetragonisca fiebrigi, Tetragona clavipes, Frieseomelitta cf. flavicornis, Lestrimelitta rufipes. The dominant species was Paratrigona lineata, comprising $82.47 \%$ of all species collected.
\end{abstract}

Keywords: native bees, pollinators, stingless bees.

\section{Diversidade de Meliponini e demais Apiformes (Apidae sensu lato) em fragmento de Cerrado e entorno, Campo Grande, MS}

Resumo: O objetivo deste estudo foi avaliar a diversidade de Meliponini e demais apiformes (Apidae sensu lato) de um fragmento de Cerrado e seus arredores. Armadilhas de Malaise foram instaladas em área de pastagem próximas a fragmento de Cerrado, de outubro a dezembro de 2010. As amostras foram coletadas em intervalos de sete dias e conservadas em solução de Dietrich. Das amostras foram separados os espécimes apiformes em morfoespécies e enviadas para identificação. A tribo Meliponini foi a mais abundante em áreas abertas de pastagem que em áreas de fragmento de Cerrado. As espécies de Meliponini presentes foram de Meliponini Trigona gr. fulviventris, Paratrigona lineata, Trigona recursa, Partamona sp, Trigona spinipes, Trigona gr. hyalinata, Trigona gr. fulviventris, Tetragonisca fiebrigi, Tetragona clavipes, Frieseomelitta cf. flavicornis, Lestrimelitta rufipes. A espécie dominante com $82,47 \%$ de indivíduos coletados foi Paratrigona lineata.

Palavras-chave: abelhas nativas, polinizadores, abelhas sem ferrão. 


\section{Introduction}

Bees are responsible for the pollination of plants in general, ensuring the fruit formation and the perpetuation of plant species. On the other hand, bees are rewarded with nectar supply and pollen from the plant flowers visited. According to Kerr et al. (1996), these insects are responsible for 40 to $90 \%$ of the pollination of native plants in a tropical environment. They are the best pollinator in Cerrado Biome, where they pollinate 60 to $75 \%$ of all plants species (Silberbauer-Gottsberger \& Gottsberger 1988).

In Brazil there are about 3,000 bee (Apidae) species described, from a total of 17,533 bee species described in the world, with recent estimations of 20,000 (Michener 2007). Many species of native bees are in danger of extinction for several reasons. Among the main factors responsible for the extinction of bees are the fragmentation of original vegetation and the use of non-selective insecticides (Turner 1996, Kerr et al. 1996). Bees of the Tribe Meliponini, otherwise known as native stingless bees, are important pollinators for plants like strawberry, guarana, açai, coffee, and other cultivated species (Malagodi-Braga \& Kleinert 2004).

The maintenance of honeybees in the field is very important for crop plants, but this practice is not very common in developing countries. In the United States the annual value of pollination by bees has been estimated at US\$ 14,6 billion, thus justifying its importance for agriculture (Morse \& Calderone 2000). The levels of plant pollination in Brazil are usually unsatisfactory, which cause reduction of crop yields, particularly those that depend on pollinators such as bees (Imperatriz-Fonseca 2010).

Currently, public policies are being discussed in order to assess the necessity of maintain native vegetation areas, their efficiency in maintaining beneficial organisms in adjacent areas, and how to measure this efficiency or interference in the altered environment. According to Freitas et al. (2009), the causes of pollinators' population declining in agricultural areas may be the deforestation of native vegetation, inadequate use of agricultural practices, such as the use of pesticides and monoculture. Native vegetation areas have nectar and pollen source plants for pollinators, and continuously provide flowers throughout the year for nesting and breeding (Larsen et al. 2005). However, little attention has been given to the impact of agricultural products on pollinators, especially in cultivated areas (Freitas \& Pinheiro 2010). Identifying the diversity of bees present in cultivation sites close to native vegetation areas can become a tool in the evaluation of the effect of agricultural practices.

Therefore, the aim of this work was to estimate the diversity of Apidae family (sensu lato) in a Cerrado fragment and its surrounding in Campo Grande, MS, Brazil.

\section{Material and Methods}

The experiment was performed at an experimental area on São José farm, Campo Grande, MS, in October, 2010. The experimental area was divided into three sub areas in two different environments, inside and outside the of the Cerrado fragment. Six Malaise traps (Townes 1972) were installed, three in the outside fragment area (A) and three inside the Cerrado fragment area (B). A distance of 100 meters separated each Malaise trap installed. The geographical coordinates per site of collection were: In Pasture area: 1) Latitude 20²4'13.16”S and Longitude 54 $36^{\prime} 45.69^{\prime \prime} \mathrm{W}$; 2) Latitude 20 24'09.60”S and Longitude 54³6'47.32'W; 3 ) Latitude $20^{\circ} 24^{\prime}$ '03.62'S and Longitude

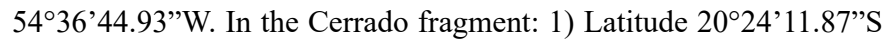
and Longitude 54 $36^{\prime} 42.20^{\prime \prime} \mathrm{W}$; 2) Latitude $20^{\circ} 24^{\prime} 08.35^{\prime} \mathrm{S}$ and Longitude 54³6'43.83”'W; 3) Latitude 20²4'06.22”S and Longitude $54^{\circ} 36^{\prime} 42.63^{\prime \prime} \mathrm{W}$.

The samples were collected once a week, during a period of four weeks. The collected material was packed in glass vials containing $70 \%$ alcohol. In the laboratory the Apidae family (sensu lato) (apiforms) were removed from the total samples and were separated in Tribe Apini, Meliponini, Bombini and Euglossini. Dr. Gabriel Mello from Universidade Federal do Paraná, PR, carried out the Identification.

The type of soil is neossolo and the climate is humid tropical, characterized by a pronounced dry season in the winter and rainy season in summer, annual average temperature is $23.0^{\circ} \mathrm{C}$. At the time the experiments were carried out the temperature was high and there was a lot of rain. The seasonal climate date was obtained from a center installed at the University Farm (Table 1).

The area has three remaining fragments of the original vegetation of Cerrado Biome and constitute the Legal Reserve of the Property according to the current Forest Code. These three areas have 9.9 ha, 5.2 ha and 0.6 ha respectively, comprising a total of 15.6 ha of native vegetation. The most common trees in the area are Pau-terra-folhagrande (Qualea grandiflora Mart.), pau-terra-folha-pequena (Qualea multiflora Mart.), pau-pombo (Matayba ghuianensis Aubl.), Capororoca (Myrsine ferrugínea Spreng.), pimenta-de-macaco (Xylopia aromatica (Lam.) Mart.) and lixeira (Curatella americana L). These species together make up more than $50 \%$ of the wealth of the three fragments of tree presents. Some species of figueira (Moraceae) and many individuals of Alibertia sessilis Vell. K. Schum. (marmelinho do campo) are common, and occurs in high frequency and have wide distribution. In open areas (pasture), the lighting changes the composition edge, favoring some individuals like Dipteryx alata Vogel (Cumbaru), Cecropia pachystachya Trécul. (Embankment) and Annona crassiflora Mart. (Marolo).

\section{Results and Discussion}

There were 994 bees of the Apinae subfamily (Corbiculate bees), collected from two areas (Pasture and Cerrado) during four weeks. In total, 726 individuals were sampled from pasture sites and 268 individuals were sampled from Cerrado fragment sites. The most abundant tribe was Meliponini $(n=672 ; 72 \%$ in Pasture and $n=258$; $26 \%$ in Cerrado), followed by Bombini ( $n=14 ; 12$ in Pasture and 2 in Cerrado), Apini ( $\mathrm{n}=2,2$ in pasture and 0 in Cerrado), Euglossini ( $\mathrm{n}=4$; 2 in Pasture and 2 in Cerrado) and other Apiforms ( $n=44 ; 40$ in pasture and 4 in Cerrado) (Table 2).

In this study, nine species from Meliponini were found: Frieseomelitta cf. flavicornis (Fabricius 1798), Lestrimelitta rufipes (Friese 1903), Paratrigona lineata (Lepeletier 1836), Partamona sp., Tetragona clavipes (Fabricius 1804), Tetragonisca fiebrigi (Schwarz 1938), Trigona gr. fulviventris (Guérin 1844), Trigona gr. hyalinata (Lepeletier 1836), Trigona recursa (Smith 1863), Trigona spinipes (Fabricius 1793), one morphospecies from Bombini (Bombus sp. 1); one specie from Apini (Apis mellifera Linnaeus 1758); two morphospecies from Euglossini and seven from other Apidae s. lato, Tropidopedia 
Meliponini and anothers Apiformes in Cerrado

Table 1. Weekly climate data, average temperature, total precipitation and average Wind velocity, in the experimental area, latitude $20^{\circ} 26^{\prime} 50^{\prime \prime} \mathrm{S}$ and longitude $54^{\circ} 43^{\prime} 21^{\prime \prime}$, Campo Grande, MS, October, 2010.

\begin{tabular}{|c|c|c|c|}
\hline Sampling date & $\begin{array}{c}\text { Average Temperature }\left({ }^{\circ} \mathrm{C}\right) \\
\text { (max-min) }\end{array}$ & $\begin{array}{c}\text { Total Precipitation (mm) } \\
\text { (max-min) }\end{array}$ & $\begin{array}{l}\text { Average Wind (km/h) } \\
\text { (max-min) }\end{array}$ \\
\hline $04 / 10 / 2010$ & $21.98(34.2-13.9)$ & $12.4(2.2-0.0)$ & $7.01(33.8-22.5)$ \\
\hline $11 / 10 / 2010$ & $23.41(32.8-25.3)$ & $3.2(2.0-0.0)$ & $8.34(11.6-3.1)$ \\
\hline $18 / 10 / 2010$ & $24.40(34.8-17.2)$ & $51.6(54.4-0.0)$ & $7.0(12.9-2.3)$ \\
\hline $25 / 10 / 2010$ & $21.83(34.3-13.4)$ & $43.40(26.4-0.0)$ & $7.72(13.4-3.3)$ \\
\hline
\end{tabular}

Table 2. Numbers of Apidae and other apiforms specimens, collected during four weeks, in Malaise traps, in pasture areas, around Cerrado fragment, Campo Grande, MS, October, 2010.

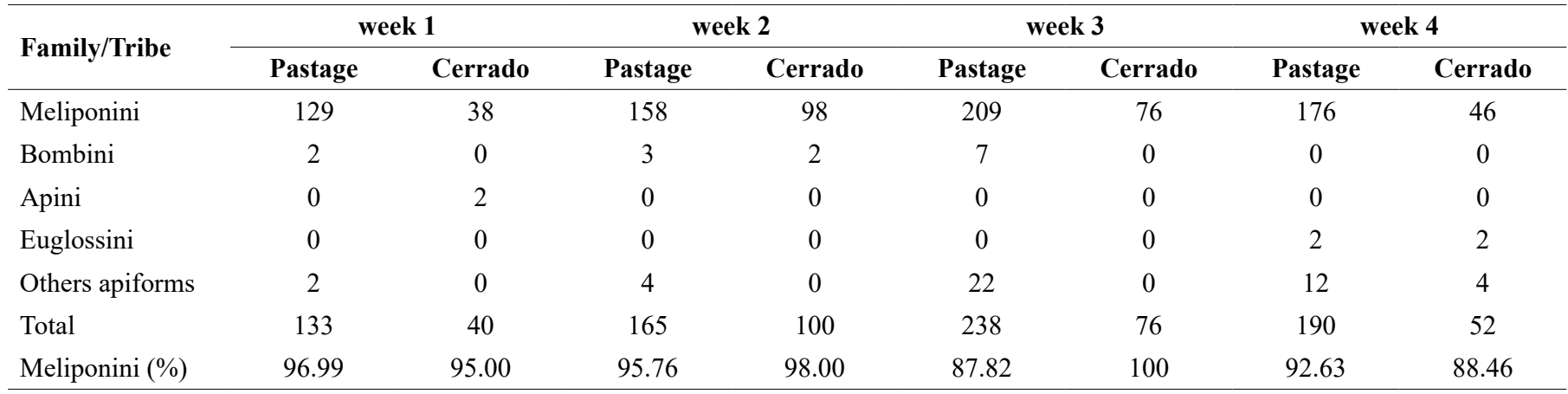

flavolineata (Aguiar \& Melo 2007) (Tapinotaspidini), Exomalopsis sp. 1. (Exomalopsini), Halictinae - seven morphospecies. Meliponini was the predominant tribe in the two environments, the Cerrado fragment and pasture around.

In this area few individuals (2) of Apis mellifera (Apinae) were found. Krug \& Alves-dos-Santos (2008) reported from surveys in Santa Catarina that the dominant bee was Peponapis fervens (Eurecini) showing 51\% of all visits to flowers, followed by $A$. mellifera with $46 \%$ and the other three species of native bees represented $3 \%$ of all visits to the pumpkin flowers. D'Avila \& Marchini (2008), working in a Cerrado area in São Paulo State, observed greater abundance of the subfamily Apidae, or A. mellifera (55.8\%), followed by Trigona spinipes (14.4\%) and Exomalopsis sp. (8.3\%). The authors concluded that the low diversity of bees might be due to fragmentation and the plantation of exotic species (Pinus and Eucalyptus) in the surroundings areas of this fragment. In a survey developed at the Private Reserve of Natural Heritage Eliezer Batista, State of Mato Grosso do Sul, Aoki et al. (2012) reported bees belonging to A. mellifera as the most abundant species (50\% of total).

It was observed a variation according to the collection area (pasture and cerrado fragment) and sampled week (Figure 1). This could be explained by the fact that these insects are known as good flyers and live in social colonies. As a consequence, it could increase the probability of occasional catches in certain areas, with varying resource availability. The local climate, temperature, rain and wind may also help to understand the changes between different weeks of collection. The predominance of stingless bees (Meliponini) in the pasture area (Figure 1) may be due to a large capacity of flight to catch pollen from the flowers, which is more accessible in open areas.

In the pasture area it was observed an increase in the abundance of Meliponini at the three first weeks, with 129, 158, and 209 individuals captured. But in the fourth week a reduction was observed (176) (Figure 1). When fewer individuals were collected, it was observed a decrease in temperature (Table 1).

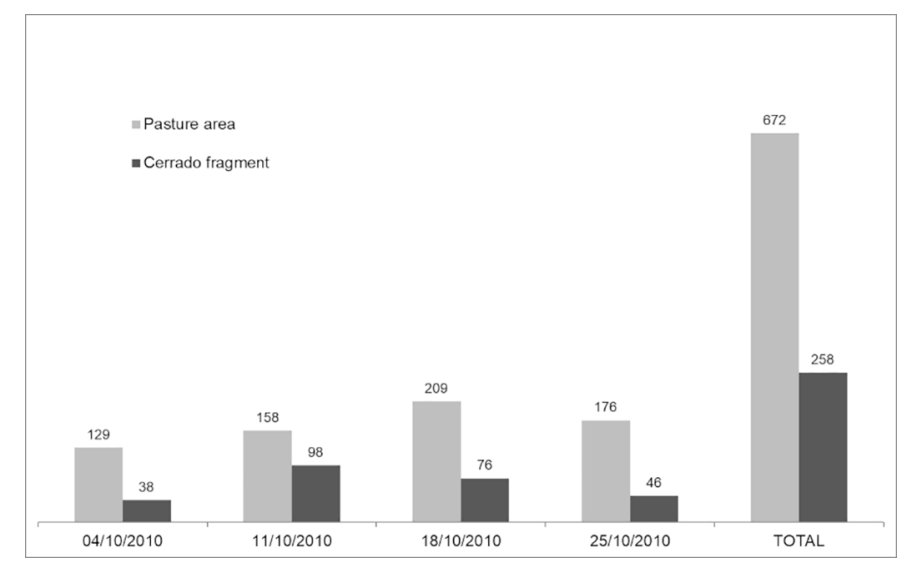

Figure 1. Abundance flutuation of Meliponini, collected during four weeks in Malaise traps in Pasture area around a Cerrado fragment. Campo Grande, MS, October, 2010.

The average temperature during the experiment ranged from 19 to $24^{\circ} \mathrm{C}$, indicating excellent conditions for foraging. However, in the third and fourth week, heavy rains occurred with a total of 51.6 and 43.40 $\mathrm{mm}$ (Table 1). This cannot be the cause of a reduction in the number of collected individuals observed in all experimental areas.

Considering only Meliponini in the Cerrado fragment, it was observed a small number of stingless bees compared to the pasture area, for all traps, totalizing 258 individuals, whereas in the pasture area, 672 individuals of stingless bees were collected. However, a reduction was observed in the first and fourth week of collection (pasture and Cerrado fragment). In addition, an increase in the third week was observed (Figure 1).

The population dynamics of insects in the field is directly related to weather conditions, rain, wind and especially temperature. According to Silveira Neto et al. (1995) temperature is an important factor in the activity of the bees, which prefer a time of the day when the temperature 
is around $25^{\circ} \mathrm{C}$ for foraging. Thomazini \& Thomazini (2002) reported that an increase in temperature and less rain, increased bee numbers, at Rio Branco, Acre.

According to Kerr et al. (1996) around 400 species of Meliponini were described and at least 100 are in danger of extinction due to human activities, and to the loss of natural habitats. According to ImperatrizFonseca (2010) it is necessary the conservation of the forest for the maintenance of bee populations and pollination services on agricultural landscapes.

The colonies of stingless bees, unlike Apini, have multiple queens or bee masters, but only one queen is fertilized. In order to breed, the worker bee stay in the alveoli, which is full of honey, pollen and glandular secretions, where the larvae feed alone. The honey is deposited in pots of wax nests of hollow trees, wood and abandoned termite mounds. However, the species Trigona spinipes (Fabr.), bee Arapuá, is a citrus pest, which destroys leaves and flowers. In the case of native bees, which are social insects, pollen is used to feed the larvae, after collected from nearby plants. Therefore, the availability of flowers also influences the dynamics of the population. Social bees have no food preference, like Apis mellifera (Apinae) and T. spinipes (Meliponini), which explains the abundance of different species of plants (D'Avila \& Marchini 2008).

In this study the most frequent species was Paratrigona lineata (Lepeletier 1836) with $82 \%(n=767)$ of all Meliponini captured, $72 \%$ in pasture and $28 \%$ in Cerrado area. A lower proportion was Trigona gr. fulviventris with $15 \%$ (137) of individuals captured, $41 \%$ in pasture and $59 \%$ in Cerrado area. The other species identified were only occasionally collected and in fewer numbers. Most individuals were captured in traps in the pasture area, 100 meters from the Cerrado fragment, with a total of 672 individuals. For the traps in the forest, a total of 258 individuals were captured, however, the same proportion of was maintained (Figure 2).

According to Caceres \& Legendre (2009) 'indicator species" are recognized by ecologists when they are restricted to one or a few habitat types. In this study all species of Meliponini occurred in both sites. Therefore we were not able to point out an indicator species to monitor environmental changes.

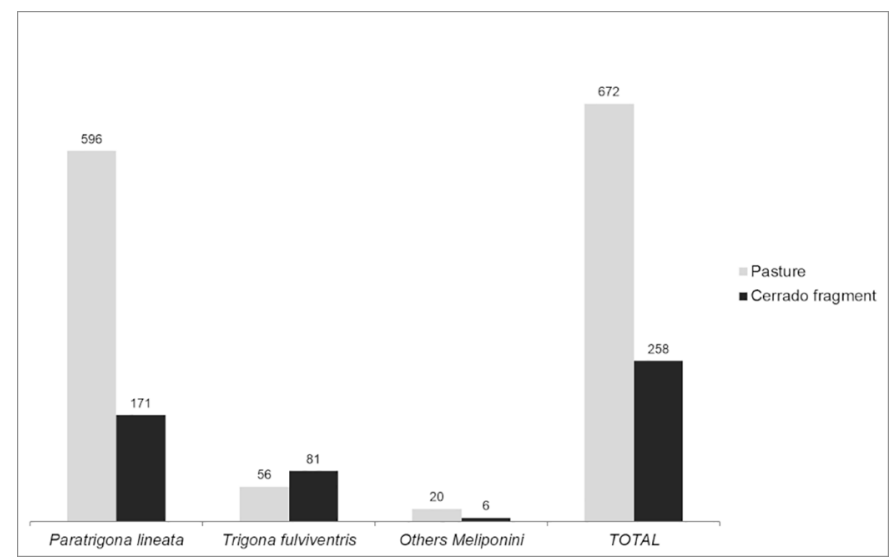

Figure 2. Paratrigona lineata, Trigona fulviventris and another Meliponini in two environments (Pasture and Cerrado fragment), October, 2010, Campo Grande, MS.
Lima \& Silvestre (2017) cataloged 386 species of bees (Apidae s. lato) in Mato Grosso do Sul, with citation of some species of Meliponini also recorded in the present study, such as Paratrigona lineata, Tetragonia clavipes, Tetragonisca fiebrigi, Trigona hyalinata. In this context, this study presents four new occurrence records for the state of Mato Grosso do Sul, Frieseomelitta cf. flavicornis (Fabricius 1798), Lestrimelitta rufipes (Friese 1903), Trigona gr. fulviventris (Guérin 1844), and Trigona recursa (Smith 1863).

\section{Conclusions}

The Meliponini was the most abundant Tribe in the area of study, most of them were captured in open areas around the Cerrado fragment. The species present in this area were Trigona gr. fulviventris, Paratrigona lineata, Trigona recursa, Partamona sp, Trigona spinipes, Trigona gr. hyalinata, Trigona gr. fulviventris, Tetragonisca fiebrigi, Tetragona clavipes, Frieseomelitta cf. flavicornis, Lestrimelitta rufipes. The first most abundant species was Paratrigona lineata and the second one Trigona fulviventris. Moreover, this study present new data on the species occurrence for Mato Grosso do Sul state.

\section{Acknowledgments}

To Centro de Pesquisas do Pantanal (CPP), Instituto Nacional de Ciência e Tecnologia em Áreas Úmidas (INAU) - Programa Institutos Nacionais de Ciência e Tecnologia - CNPq/MCT, Fundação de Suporte para o Ensino, Ciência e Tecnologia do estado do Mato Grosso do Sul (FUNDECT).

\section{Author Contributions}

Antonia Railda Roel: Substantial contribution to the design and design of the work; Contribution to data acquisition: Contribution in the analysis and interpretation of data; Contribution in the writing of the work; Contribution in critical review adding intellectual content.

Armando Araujo Neto: Contribution to data acquisition.

Kwok Chiu Cheung: Substantial contribution to the design and design of the work; Contribution to data acquisition.

Felipe Varussa de Oliveira Lima: Contribution in the analysis and interpretation of data; Contribution in the writing of the work; Contribution in critical review adding intellectual content.

Ricardo Dias Peruca: Substantial contribution to the design and design of the work; Contribution to data acquisition; Contribution in the analysis and interpretation of data; Contribution in the writing of the work; Contribution in critical review adding intellectual content.

Leticia Vieira da Silva: Contribution to data acquisition.

Suellen Soares: Contribution to data acquisition.

\section{Conflicts of interest}

The authors declare that they have no conflict of interest related to the publication of this manuscript. 


\section{References}

AOKI, C., TEIXEIRA-GAMARRA, M.C., BARÔNIO, G.J., SIGRIST, M.R. \& LAROCA, S. 2012. Diversidade de abelhas (Hymenoptera: Apoidea) e Recursos Florais na RPPN Engenheiro Eliezer Batista, Pantanal de Mato Grosso do Sul. p. 82-111. In: Rabelo, A.P.C.; Moreira, V.F.; Bertassoni, A.; Aoki, C., eds. Descobrindo o Paraíso Aspectos Biológicos da Reserva Particular do Patrimônio Natural. Instituto Homem Pantaneiro, Rio de Janeiro, RJ, Brazil.

CÁCERES, M.D. \& LEGENDRE, P. 2009. Associations between species and groups of sites: indices and statistical inference. Ecology, v. 90, n. 12, p. 3566-3574.

D'AVILA, M. \& MARCHINI, L. C. 2008. Análise faunística de himenópteros visitantes florais em fragmento de cerradão em Itirapina, SP. For. Sci., v. 18 , n.2, p. 271-279.

IMPERATRIZ-FONSECA, V.L. 2010. Conservação de polinizadores no ano internacional da biodiversidade. Oecolog. Australis, v. 14, p. 14-15.

FREITAS, B.M., IMPERATRIZ-FONSECA, V.L., MEDINA, L.M., KLEINERT, A.M.P., GALLETO, L., NATES-PARRA, G. \& QUEZADA-EUÁN, J.J.G. 2009. Diversity, threats and conservation of native bees in the Neotropics. Apidologie, v.40, p. 332-346.

FREITAS, B.M. \& PINHEIRO, J. N. 2010. Efeitos sub-letais dos pesticidas agrícolas e seus impactos no manejo de polinizadores dos agroecossistemas brasileiros. Oecol. Aust., v. 14, p. 282-298.

KERR, W.E., CARVALHO, G.A. \& NASCIMENTO, V.A. 1996. Abelha uruçu: biologia, manejo e conservação. Acangaú, Belo Horizonte, MG, Brasil.

KRUG, C. \& ALVES-DOS-SANTOS, I. 2008. Use of different methods to sample the bee fauna (Hymenoptera: Apoidea): a study in mixed temperate rainforest in Santa Catarina state. Neotrop. Entomol., v. 37, n. 3, p. 265-278.
LARSEN, T.H., WILLIAMS, N.W. \& KREMEN, C. 2005. Extinction order and altered community structure rapidly disrupt ecosystem functioning. Ecol. Lett., v. 8, p. 538-547.

LIMA, F.V.O. \& SILVESTRE, R. 2017. A fauna de abelhas (Hymenoptera, Apidae sensu lato) de Mato Grosso do Sul, Brasil. Iheringia. Sér. Zoo., v.107, Suppl.: e2017123.

MALAGODI-BRAGA, K.S. \& KLEINERT, A.D.P. 2004. Could Tetragonisca angustula Latreille (Apinae, Meliponini) be effective as strawberry pollinator in greenhouses? Aust. J. Agric. Res., v. 55, p. 771-773.

MICHENER, C.D. 2007. The bees of the world. 2ed. Johns Hopkins University, Baltimore, MD, USA, 992pp.

MORSE, R.A. \& CALDERONE, N.W. 2000. The value of honey bees as pollinators of U.S. crops in 2000. Bee Culture v. 128, p. 1-15.

SILBERBAUER-GOTTSBERGER, I. \& GOTTSBERGER, G. 1988. The pollinization of Cerrado plants. Rev. Bras. de Biol, v. 48, p. 651-663.

SILVEIRA NETO, S., MONTEIRO, R.C., ZUCCHI, R.A. \& DE MORAES, R.C.B. 1995. Faunistic insect analysis for environmental change evaluation. Sci. Agric., v. 52, n. 1, p. 9-15.

THOMAZINI, M.J. \& THOMAZINI, A.P.B.W. 2002. Bee diversity (Hymenoptera: Apoidea) in inflorescences of Piper hispidinervum (C.DC.). Neotrop. Entomol., v. 31, n. 1, p. 27-34.

TOWNES, H.A. 1972. A light-weight malaise trap. Entomol. News, v. 83, p. 239-247.

TURNER, I.M. 1996. Species loss in fragments of tropical rain forest: a review of the evidence. J. Appl. Ecol., v. 33, p. 200-209. 